\title{
PERAN DINAS SOSIAL DALAM MEMBENTUK LIFE SKILL ANAK JALANAN DI KOTA SERANG
}

(Studi Deskriptif Dinas Sosial Kota Serang)

\author{
Lady Diana ${ }^{1}$, Dinar Sugiana Fitrayadi ${ }^{2}$, Ria Yuni Lestari ${ }^{3}$ \\ Dosen Program Studi PPKn FKIP Universitas Sultan Ageng Tirtayasa \\ Serang, Indonesia \\ Lady8817@gmail.com ${ }^{1}$, dinar.sugiana@untirta.ac.id ${ }^{2}$
}

\begin{abstract}
The purpose of this study: 1) to determine the Role of the Social Service in Shaping the Life Skill of Street Children in Serang City 2) to find out the Activities carried out by the Social Service in Shaping the Life Skill of street children in the City of Serang 3) to find out the Obstacles experienced by the Social Service in forming Life Skill of street children in Serang City. The method used: descriptive method with a qualitative approach. The instruments used: observation, interviews, and documentation. Research subjects: Serang City Social Service and Street Children in Serang City. The results of this study indicate that the Role of Social Services in Shaping the Life Skill of Street Children in Serang City through self-knowledge, rational thinking skills, social skills, academic skills, and vocational skills provided by social services in training program activities aimed at street children have the skills or abilities, able, and skilled to maintain the survival and development in the future. Activities undertaken by the Social Service in Forming Life Skills of street children: hindering activities and leadership training activities. Barriers experienced by the Social Service in forming Life Skills of street children: internal and external barriers which include internal obstacles in the submission of programs and target participants, external barriers include barriers to screening / blocking street children, it is difficult to change the mindset of street children and parents who are blocking follow-up process in handling street children.
\end{abstract}

Keywords: Serang City Social Service, Life Skill, Street Children.

\section{PENDAHULUAN}

Negara Indonesia merupakan Negara berkembang yang memiliki tujuan sesuai dengan Undang-Undang Dasar 1945, mengandung arti bahwa Negara mempunyai kewajiban untuk melindungi Bangsa Indonesia dari berbagai ancaman baik yang datang dari dalam maupun dari luar sehingga keselamatan seluruh Bangsa Indonesia dan seluruh tumpah darah Indonesia terjamin dan dapat melaksanakan seluruh hak dan kewajibannya. Semua anak memiliki hak yang sama termasuk anak jalanan yang juga memiliki hak pendidikan, hak kesehatan, dan hak perlindungan. Dalam menjamin hak-hak tersebut maka pemerintah menerapkan kebijakan berupa Undang-Undang perlindungan anak yang tertera pada Undang-Undang Republik Indonesia Nomor 35 tahun 2014 tentang perubahan atas Undang-Undang nomor 35 tahun 2002 tentang perlindungan anak yang di dalamnya memuat bahwa setiap anak berhak atas kelangsungan hidup, 
tumbuh dan berkembang serta berhak atas perlindungan dari kekerasan dan dikriminasi sebagaimana diamanatkan dalam Undang-Undang Dasar Negara Republik Indonesia Tahun 1945 dan dan bahwa anak sebagai tunas, potensi, dan generasi muda penerus cita-cita perjuangan Bangsa memiliki peran strategis, ciri dan sifat khusus sehingga wajib dilindungi dari segala bentuk perlakuan tidak manusiawi yang mengakibatkan terjadinya pelanggaran hak asasi manusia.

Setiap anak memang seharusnya hidup dalam kegembiraan apa lagi dalam masa pertumbuhan, namun dalam kenyataannya tidak semua anak hidup dalam kegembiraan sebagian dari mereka mengalami keterpurukan kesedihan dan kesengsaraan atas dasar ekonomi yang kurang, seperti halnya anak jalanan yang sering kita temui di tempat-tempat yang ramai seperti di pasar, di terminal, dan di pusat perkotaan. Anak jalanan memiliki pandangan yang negatif dari masyarakat, karena dianggap meresahkan masyarakat, sebagian dari mereka di terjerumus dalam tindakan kriminal seperti mencopet, mencuri dan tindakan kriminal lainnya, namun tidak semua anak jalanan seperti itu, dengan sedikit uang yang diperolehnya dari mengamen atau memulung dan sebagainya mereka gunakan untuk bertahan hidup di tengah arus kota, pekerjaan anak jalanan ini seharusnya perlu penanganan dari pemerintah daerah yang mana mereka yang seharusnya masih duduk di bangku sekolah tetapi berada di jalan untuk mencari nafkah. Kota Serang banten merupakan pusat keramaian kota, Berdasarkan hasil prapenelitian yang peneliti lakukan di Dinas Sosial Peneliti mendapatkan data jumlah anak jalanan dan jumlah anak yang terbina dari tahun 2016 sampai tahun 2019 yakni :

\section{Tabel 1.1}

\section{Jumlah Anak Jalanan}

\begin{tabular}{|c|c|c|c|}
\hline Tahun & $\begin{array}{l}\text { Jumlah } \\
\text { anak } \\
\text { jalanan }\end{array}$ & $\begin{array}{c}\text { Jumlah } \\
\text { anak } \\
\text { terbina }\end{array}$ & $\begin{array}{c}\text { Persentase } \\
\text { jumlah } \\
\text { anak } \\
\text { terbina }\end{array}$ \\
\hline 2016 & 181 & 110 & $61 \%$ \\
\hline 2017 & 181 & 50 & $28 \%$ \\
\hline 2018 & 113 & 60 & $53 \%$ \\
\hline 2019 & 142 & 60 & $42 \%$ \\
\hline
\end{tabular}

Pada tahun 2016 jumlah anak jalanan mencapai 180 anak dan anak yang tertangani berjumlah 110 anak, di tahun 2017 jumlah anak jalanan mencapai 181 anak dan anak yang tertangani berjulah 50 orang, di tahun 2018 jumlah anak jalanan yaitu 113 anak dan anak yang sudah tertangani yaitu 60 anak dan pada tahun 2019 jumlah anak jalanan mencapai 142 dan anak yang sudah tertangani berjumlah 60 anak. Dalam data tersebut terlihat bahwa memang adanya perbedaan dalam setiap tahunnya karena memang adanya 
keterbatasan dana dalam penanganan anak jalanan dan dalam hal ini dinas sosial juga melihat dari kesungguhan anak yang mau untuk di bantu dan bersedia untuk mendapatkan pelatihan yang di berikan, karena apa bila memberikan penanganan atau pembinaan yang tidak diinginkan oleh anak jalanan tersebut akan sia-sia pembinaan tersebut.

Data dilapangan menunjukkan bahwa Dinas sosial kota Serang melakukan pembinaan untuk membentuk kecakapan hidup anak jalanan melalui berbagai program. Menurut Anwar (2012: 20) menyatakan bahwa pendidikan kecakapan hidup adalah pendidikan yang dapat memberikan bekal keterampilan yang praktis, terpakai, terkait dengan kebutuhan pasar kerja, peluang usaha dan potensi ekonomi atau industri yang ada di masyarakat. Life skills ini memiliki cakupan yang luas, berinteraksi antara pengetahuan yang diyakini sebagai unsur penting untuk hidup lebih mandiri. Makadari itu perlu adanya pendidikan kecakapan hidup bagi anak jalanan agar meka memiliki bekal keterampilan agar dapat bermanfaat dalam kehidupannya dan dapat menghadapi dan memecahkan permasalahan dalam kehidupannya.

Dengan melihat latar belakang demikian penulis tertarik untuk meneliti mengenai sejauh mana peran Dinas Sosial terhadap pembinaan anak jalanan di Kota
Serang, sehingga penulis akan mengambil judul penelitian mengenai peran Dinas Sosial dalam membina life skill anak jalanan di Kota Serang.

\section{METODE PENELITIAN}

Lokasi penelitian di lakukan di Dinas Sosial Kota Serang untuk mencari data terkait anak jalanan dan penelitian selanjutnya dilakukan di tempat-keramaian seperti terminal pasar rau dan lampu merah untuk mencari informasi mengenai anak jalanan tersebut. Waktu penelitian diperkirakan mulai dari bulan April tahun 2019 sampai dengan bulan Oktober tahun 2019. peneliti menggunakan metode penelitian deskriptif dengan pendekatan penelitian kualitatif yaitu karena peneliti ingin mengetahui lebih dalam permasalahan yang berkaitan dengan membentuk Life skill anak jalanan di kota Serang dengan menggunakan teori karena peneliti akan langsung masuk ke objek dengan melakukan kegiatan observasi wawancara dan dokumentasi sehingga masalah dapat ditemukan dengan jelas. Fokus penelitian yang dilakukan oleh peneliti yaitu untuk mengetahui bagaimana peran dinas sosial dalam membentuk Life skill anak jalanan di kota Serang serta mengetahui kendala apa saja dinas sosial dalam membentuk Life skill anak jalanan di kota Serang tersebut. Teknik pengumpulan data yang akan dilakukan oleh peneliti adalah sebagai berikut : 
1. Observasi

Dalam observasi penelitian ini, peneliti berperan sebagai pengamat yang mengamati kegiatan yang dilaksanakan oleh pihak Dinas Sosial seperti kegiatan penghalauan anak jalanan, kegiatan pelatihan kepemimpinan dan kegiatan kewirausahaan yang dilaksanakan untuk menangani anak jalanan. Peneliti juga melampirkan pedoman observasi yang dijadikan sebagai data tambahan dalam penelitian.

2. Wawancara

Wawancara yang dilakukan peneliti adalah wawancara semi terstruktur. Dimana peneliti menyiapkan lampiran wawancara terstruktur namun peneliti juga melakukan wawancara dimana pertanyaannya dilakukan secara bebas namun tetap membahas permasalahan yang berkaitan dengan penelitian. Subyek penelitiannya adalah Dinas Sosial yang menangani permasalahan anak jalanan, Petugas Pos Sahabat Anak (PSA) dan anak jalanan yang ada di kota Serang

3. Studi dokumentasi

Dokumentasi yang dilakukan peneliti adalah dokumentasi secara langsung, dimana dokumentasi dilakukan saat peneliti sedang melakukan observasi atau wawancara kepada subyek penelitian. Penelitian ini menggunakan jenis dokumentasi berupa foto kegiatan atau aktivitas yang berkaitan dengan peran Dinas Sosial dalam membentuk Life Skill anak jalanan.

Tekni pemeriksaan dan pengecekan keabsahan data yang akan peneliti lakukan pada penelitian ini ialah menggunakan teknik triangulasi

\section{TEMUAN PENELITIAN}

\section{Peran Dinas Sosial dalam Membentuk Life Skil Anak Jalanan di Kota Serang}

Peran Dinas Sosial dalam Membentuk Life Skil Anak Jalanan Di Kota Serang meliputi pembinaan mengenai kecakapan mengenal diri, kecakapan berfikir rasional, kecakapan sosial, kecakapan akadimik dan kecakapan vokasiona yang bertujuan agar anak jalanan tersebut dapat memiliki skill atau kemampuan agar tidak berada di jajalan kembali. Hal ini sesuai dengan teori menurut Departemen Pendidikan Nasional dalam anwar (2012:28) yang membagi Life Skill (Kecakapan Hidup) menjadi empat jenis yaitu : (1) kecakapan personal (Personal Skill) yang mencakup kecakapan mengenai diri (self awarness) dan kecakapan berfikir rasional (thinking skills) 
kecakapan sosial (social skills) (3) kecakapan akademik (akademik skills), (4) kecakapan vokasional (vocational skills), dan teori menurut WHO dalam Sutardi (2016:65) mendefinisikan bahwa kecakapan hidup sebagai ketrampilan atau kemampuan untuk dapat beradaptasi dan berperilaku positif yang memungkinkan seseorang mampu menghadapi berbagai tuntutan dan tantangan dalam kehidupan secara lebih efektif, kecakapan hidup mencakup lima aspek yakni : (1) kecakapan mengenal diri, (2) kecakapan berfikir, (3) Kecakapan Sosial, (4) kecakapan akademik dan, (5) Kecakapan kejuruan. Sedangkan menurut Barrie Hopson dan Scally dalam Rusman (2011:505) mengemukakan bahwa kecakapan hidup merupakan pengembangan diri untuk dapat bertahan hidup, tiumbuh, dan berkembang, memiliki kemampuan untukberkomunikasi dan berhubungan baik secara individu, kelompok maupun melalui sistemdalam menghadapi situasi tertentu. pengertian kecakapan hidup dalam pandangan ini tidak semata memiliki kemampuan vokasional, namun juga memiliki kemampuan dasar pendukung secara fungsional. Adapun tujuan kecakapan hidup menurut Kamil (2012:130-131) tujuan utama peningkatan pendidikan kecakapan hidup adalah untuk menyiapkan masyarakat agar yang bersangkutan mampu, sanggup, dan terampil menjaga kelangsungan hidup dan berkembangnya di masa datang. Esensi dari peningkatan kecakapan hidup adalah untuk meningkatkan relevansi pembangunan dengan nilai-nilai kehidupan nyata, baik preservatif maupun progresif.

\section{a. Kecakapan mengenali diri}

Menurut Anwar (2012:29) bahwa Kemampuan mengenali diri pada dasarnya merupakan penghayatan diri sebagai makhluk Tuhan yang Maha Esa, anggota masyarakat dan warga Negara serta menyadari dan mensyukuri kelebihan dan kekurangan yang dimiliki, sekaligus menjadikannya sebagai modal dalam meningkatkan dirinya sebagai individu yang bermanfaat bagi diri sendiri dan lingkungannya. Sedangkan menurut Tim pengembangan Ilmu pendidikan (2007:357) kecakapan mengenal diri (self awareness) mencakup: (1) penghayatan diri sebagai makhluk tuhan yang maha esa, anggota masyarakat dan warga 
negara, (2) menyadari dan mensyukuri kelebihan dan kekurangan yang dimiliki, sekaligus menjadikannya sebagai modal dalam meningkatkan dirinya sebagai individu yang bermanfaat bagi sendiri dan lingkungannya. Menurut Depdiknas (2007:11) Kecakapan personal mencakup kesadaran diri dan berpikir rasional. kesadaran diri disini lebih difokuskan pada kemampuan peserta didik untuk melihat potretnya sendiri dalam lingkungan keluarga, kebiasaannya, kegemarannya dan sebagainya. Sedangkan kecakapan berpikir lebih terfokus dalam menggunakan rasio atau pikiran yang meliputi menggali informasi, mengolah informasi, dan mengambil keputusan secara cerdas, serta mampu memecahkan masalah secara tepat dan baik.

Sesuai dengan teori tersebut peneliti menyimpulkan dari hasil observasi, dokumentasi dan wawancara kepada beberapa responden tersebut pembinaan dari dinas sosial kepada anak jalanan mengenai kecakapan mengenal diri yaitu meliputi:

$$
\text { Pertama mengenai }
$$$$
\text { menjalankan kewajiban dalam }
$$

agamannya yaitu dengan melalui sentuhan hati seperti memberi nasehat contohnya mengenai solat yang harus tepat waktu seperti pada kegiatan pelatihan kepemimpinan yaitu adanya kegiatan solat berjamaah untuk anak jalanan, memberikan pemahaman kepada mereka dan juga memberikan masukan agar mereka tidak salah jalan seperti selalu menjalankan kewajiban agamanya yaitu solat dan mengaji. melalui kegiatan ceramah, kegiatan ramadhan dan juga pada program pelatihan kepemimpinan yang mana di dalam kegiatan tersebut salah satunya memberikan memberikan materi kepada mereka mengenai agama dan mengarahkan ke hal yang positif seperti memberikan pentingnya solat lima waktu, mengaji dan juga berperilaku baik saling membantu satu sama lain dan tidak bermusuhan.

Kedua yaitu berperilaku jujur dengan cara menasehati memberikan pembinaan seperti prilaku jujur terhadap diri sendiri dan tuhannya seperti tidak berbohong dan tidak mengambil yang bukan miliknya, contohnya pada saat petugas dari dinas sosial 
yang meminta untuk membelikan roko tetapi anak jalanan tersebut tetap mengembalikan sisa uang dari beli roko tersebut dan selalu mengajarkan pesan jujur tentang keagamaannya seperti menjalankan solat tanpa dipaksakan dan juga adanya pembinaan kepada anak jalanan tersebut melalui program program yang di terapkan oleh dinas sosial seperti program pelatihan kepemimpinan.

Ketiga yaitu cara memberikan penghayatan kepada diri anak jalanan mengenai saling tolong menolong seama manusia yaitu dengan cara menasehati melakukan pendekatan kepada anak jalanan tersebut seperti mendatangi rumahnya bertemu dengan orang tuanya mendengarkan keluh kesahnya agar anak jalanan tersebut lebih nyaman dengan kehadiran petugas dari dinas sosial tersebut dan dapat menasehati anak jalanan tersebut mengenai salah satunya bahwa sesama manusia harus saling tolong menolong dalam hal apapun seperti membantu teman yang sedang kesusahan atau menengok temannya yang sakit. Terbukti menurut bapak wahyu pada saat ada pembangunan mushola di dekat kantor dinas sosial kota serang anak jalanan tersebut membantu pembangunan mushola tersebut tanpa di suruh dan dengan keinginannya sendiri.

Keempat mengenai cara memberikan penghayatan kepada diri anak jalanan bahwa mereka dapat bermanfaat bagi lingkungan yaitu dengan cara memberikan motifasi pelatihan agar mereka menyadari bahwa mereka dapat bermanfaat bagi lingkungan apa bila mereka berperilaku baik, ada pula contoh nyata bahwa anak jalanan tersebut bermanfaat bagi lingkungan yaitu pada saat mereka membantu pembangunan mushola.

Kelima yaitu Untuk mengetahui dan membina kelebihan dan kekurangan anak jalanan yaitu pertama bisa dilihat dari hobi anak jalanan tersebut seperti menyanyi kedua dari program-program yang dilakukan oleh Dinas Sosial yaitu program minat dan bakat yang menampilkan bakat dari anak jalanan tersebut dan juga cara membinanya bisa dari program pelatihan kepemimpinan yang 
mana anak jalanan dilatih ketrampilan kejuruan seperti servis hp dan lain lain maka akan menjadi salah satu kelebihan sehingga setelah kita mengetahui minat dan bakatnya maka di asah dan diarahkan agar bisa bernilai positif.

Ke enam yaitu cara untuk menumbuhkan rasa percaya diri pada anak jalanan yaitu disentuh hati nuraninya di berikan motivasi dan juga pelatatihan pada kegiatan pelatihan kepemimpinan dan juga pada program minat dan bakat agar mereka bisa percaya diri dalam menampilkan bakat mereka, dan percaya diri dalam hal apapun

\section{b. Kecakapan Berfikir Rasional}

Menurut Anwar (2012:29) Kecakapan berfikir rasional, mencakup antara lain : kecakapan menggali dan menemukan informasi, kecakapan mengolah informasi dan mengambil keputusan serta kecakapan memecahkan masalah secara kreatif. Sedangkan menurut Tim pengembangan Ilmu pendidikan (2007:357) kecakapan berfikir rasional (thinking skill) mencakup : (1) kecakapan menggali dan menemukan informasi (information Searching)

kecakapan mengolah informasi dan mengambil keputusan (information processing and decision making skills), (3) kecakapan memecahkan masalah secara kreatif (creative problem solving skills). Menurut Depdiknas (2007:11) Kecakapan personal mencakup kesadaran diri dan berpikir rasional. kesadaran diri disini lebih difokuskan pada kemampuan peserta didik untuk melihat potretnya sendiri dalam lingkungan keluarga, kebiasaannya, kegemarannya dan sebagainya. Sedangkan kecakapan berpikir lebih terfokus dalam menggunakan rasio atau pikiran yang meliputi menggali informasi, mengolah informasi, dan mengambil keputusan secara cerdas, serta mampu memecahkan masalah secara tepat dan baik.

Sesuai dengan teori tersebut dari hasil observasi, dokumentasi dan wawancara kepada beberapa responden dapat disimpulkan mengenai kecakapan berfikir rasional bahwa kecakapan berfikir rasional meliputi pertama cara membina anak jalanan dalam mengenali dan mendapatkan informasi yaitu dengan cara 
memberikan pemahaman kepada mereka bahwa informasi bersifat negatif dan positif dan datang darimana saja bisa dari hp dan dari teman, dari kegiatan program pelatihan kepemimpinan pun juga diberikan pembekalan bahwa informasi ada yang negatif dan positif maka harus hati hati dan teliti apabila mendapatkan informasi, seperti halnya memberikan materi menganai bahaya narkoba dan minuman keras yang mana itu merupakan hal negatif yang harus mereka hindari dan tidak terjerumus kepada hal yang negatif tersebut.

Yang kedua yaitu cara membina anak jalanan dalam mengolah informasi dengan benar dengan cara memantau memberikan arahan agar mereka tidak terjerumus dalam hal negatif seperti bahaya narkoba dan minuman keras dan memberikan pengetahuan serta mengingatkan mengenai informasi yang baik dan yang tidak baik yang harus mereka ketahui. dengan adaya program-program seperti program pelatihan kepemimpinan yang mana dalam program tersebut pihak dinas sosial juga memberikan arahan dan mengingatkan akan bahaya narkoba dan minuman keras apabila mereka sudah mengetahui informasi mengenai narkoba dan minuman keras tersebut maka mereka akan dapat mengolah informasi tersebut bahwa narkoba dan minuman keras itu tidak baik. Yang ke tiga pembinaan kepada anak jalanan mengenai pengambilan keputusan yaitu seperti halnya pada pembinaan mengenali informasi dan mengolah informasi, pembinaan dalam pengambilan keputusan ini juga mengarahkan, memotivasi, dan mendampingi anak jalanan tersebut dalam mengetahui benar dan salah suatu informasi seperti pada materi bahaya narkoba dan minuman keras agar anak jalanan tidak terjerumus dan anak jalanan tersebut akan bisa menentukan dan mengambil keputusan setelah adanya materi atau pemahaman dari dinas sosial mengenai narkoba dan minuman keras yang dapat membahayakan dirinya.

Yang ke empat proses pembinaan pada anak jalanan dalam memecahkan suatu masalah secara kreatif yaitu dengan cara pendekatan dan motivasi yang dilakukan dalam 
kegiatan pelatihan kepemimpinan yang mana menanyakan mengenai permasalahan yang sedang mereka alami sehingga mereka bisa menyeselsaikannya dengan di bantu arahan tersebut. Kebanyakan permasalahan yang dialami oleh anak jalana tersebut yaitu mengenai permasalahan perekonomian yang mana mengharuskan mereka untuk mencari uang sendiri dengan cara berada dijalan seperti mengamen.

\section{c. Kecakapan Sosial}

Menurut Anwar (2012:30) Kecakapan sosial, mencakup antara lain: kecakapan komunikasi dengan empati dan kecakapan bekerjasama. Empati, sikap penuh pengertian dan seni komunikasi dua arah, perlu ditekankan karena yang dimaksud berkomunikasi bukan hanya sekedar menyampaikan pesan, tetapi isi dan sampainya pesan disertai dengan kesan baik, yang akan membutuhkan hubungan yang harmonis. Sedangkan menurut Tim pengembangan Ilmu pendidikan kecakapan sosial (social skills) mencakup: (1) kecakapan komunikasi dan empati (comunication skills), dan (2) kecakapan bekerjasama (colaboration skills). Menurut Depdiknas (2007:11) Kecakapan sosial dapat dipilah menjadi dua jenis utama, yaitu: 1) kecakapan berkomunikasi yang dilakukan secara lisan maupun tulisan dan, 2) kecakapan bekerjasama maksudnya adalah adanya saling pengertian dan saling membantu antar sesama untuk mencapai tujuan yang baik, karena itu merupakan suatu kebutuhan yang tidak dapat dielakkan sepanjang hidup manusia.

Sesuai dengan teori tersebut dari hasil observasi, dokumentasi dan wawancara kepada beberapa responden dapat disimpulkan mengenai kecakapan sosial bahwa meliputi pertama cara dalam membina anak jalanan mengenai komunikasi dua arah yaitu dengan memberikan pemahaman, arahan, merubah mindsetnya mengenai berbicara yang sopan dan dilihat dari proses tanya jawab dalam program pelatihan kepemimpinan mengenai tutur bahas sopan atau tidak dan mengarahkan bagaimana cara bertutur kata yang sopan. Yang ke dua pembinaan kepada anak jalanan untuk menumbuhkan rasa empati pada diri mereka yaitu dengan cara 
memberikan pengarahan motivasi, dorongan dan menanamkan sikap peduli melalui kegiatan program-program seperti program pelatihan kepemimpinan agar mereka melakukan hal positif dan saling empati. Yang ketiga cara menumbuhkan pada diri anak jalanan mengenai rasa saling kerjasama satu sama lain yaitu dengan cara memberikan pengertian, arahan, pemahaman dan motivasi serta selalu mengingatkan bahwa kerjasama antara satu sama lain itu penting karena sesuatu yang dikerjakan secara kerjasama dalam hal kebaikan akan lebih ringan dan mudah. Yang ke empat cara menumbuhkan pada diri anak jalanan mengenai rasa menghargai satu sama lain yaitu memberikan pengarahan serta pendekatan kepada anak jalanan tersebut agar memiliki rasa saling menghargai satu sama lain karena apa bila ingin dihargai maka kita harus menghargai orang lain. Yang ke lima cara menumbuhkan pada diri anak jalanan mengenai rasa pengertian antara satu sama lain yaitu dengan cara memebrikan motivasi serta arahan mengenai niai-nilai positif tentang pengertian satu sama lain karena pada dasarnya anak jalana memang memiliki rasa oengertian yang tinggi pada kelompoknya hanya tinggal mengingatkan untuk saling pengertian dalam hal yang positif.

\section{d. Kecakapan Akademik}

Menurut Anwar (2012:30)

Kecakapan akademik yang seringkali juga disebut kemampuan berfikir ilmiah pada dasarnya merupakan pengembangan dari kecakapan berfikir rasional masih bersifat umum, kecakapan akademik sudah lebih mengarah kepada kegiatan yang bersifat akademik/keilmuan. Sedangkan menurut Depdiknas (2007:13) Kecakapan akademik seringkali disebut dengan kecakapan intelektual atau kemampuan berpikir ilmiah yang pada dasarnya merupakan pengembangan dari kecakapan berpikir secara umum namun mengarah kepada kegiatan yang bersifat keilmuan. Kecakapan ini mencakup antara lain kecakapan mengidentifikasi variabel, menjelaskan hubungan suatu fenomena tertentu, merumuskan hipotesis,merancang dan 
melaksanakan penelitian. Untuk membangun kecakapankecakapan tersebut diperlukan pula sikap ilmiah, kritis, obyektif, dan transparan.

Sesuai dengan teori tersebut dari hasil observasi dan wawancara kepada beberapa responden tersebut dapat disimpulkan mengenai kecakapan sosial bahwa Pada kegiatan pelatihan pihak dinas sosial Memberikan motivasi arahan dorongan dan materi-materi untuk merubah mindset mereka seperti pemahaman karakter bahaya narkoba dan juga memberikan nilai-nilai pentingnya belajar agar anak jalanan tersebut dapat pintar dan bisa membahagiakan orang tuanya, bagi yang putus sekolah dari pihak dinas sosial juga mengadakan program sekolah seperti paket c maka apabila anaknya ingin melanjutkan sekolah akan disekolahkan.

\section{e. Kecakapan vokasional}

Menurut Anwar (2012:31) Kecakapan vokasional seringkali disebut dengan "kecakapan kejuruan" artinya keterampilan yang dikaitkan dengan bidang pekerjaan tertentu yang terdapat di masyarakat. Sedangkan menurut depdiknas (2007 :14) Kecakapan ini seringkali disebut dengan kecakapan kejuruan, artinya suatu kecakapan yang dikaitkan dengan bidang pekerjaan tertentu yang terdapat di masyarakat atau lingkungan peserta didik. Kecakapan vokasional lebih cocok untuk peserta didik yang menekuni pekerjaan yang mengandalkan keterampilan psikomotorik daripada kecakapan berpikir ilmiah. Kecakapan vokasional memiliki dua bagian yaitu: 1) kecakapan vokasional dasar yang berkaitan dengan bagaimana peserta didik menggunakan alat sederhana, misalnya obeng, palu dan sebagainya, dan 2) kecakapan vokasional khusus hanya diperlukan bagi mereka yang akan menekuni pekerjaan yang sesuai dengan bidangnya, misalnya pekerja montir, apoteker, tukang, dan sebagainya.

Sesuai dengan teori tersebut dari hasil observasi dan wawancara kepada beberapa responden Kesimpulan dalam kecakapan vokasional seperti dalam pembinaan ketrampilan kejuruan pada anak jalanan yaitu dengan cara memberikan 
pelatihan lalu memfasilitasinya melalui kegiatan pelatihan kepemimpinan seperti

membengkel, menyablon, kewirausahaan, agar mereka memiliki skill yang nantinya bisa bermanfaat bagi mereka.

\section{Kegiatan yang Dilakukan Dinas} Sosial dalam Membentuk Life Skill Anak Jalanan di Kota Serang

Dinas Sosial melakukan kegiatan atau program untuk meminimalisir anak jalanan yang ada dikota serang. Tujuan dilaksanakan kegiatan tersebut agar anak jalanan tersebut memiki skill ketrampilan dan juga memiliki pengetahuan wawasan yang luas yang mana disini anak jalanan juga memiliki hak yang sama seperti anak yang lain yaitu hak untuk dilindungi, hak untuk memiliki pendidikan dan hak untuk kesehatan. Dengan demikian anak jalanan tersebut dibina oleh dinas sosial melalui berbagai program agar mereka bisa berkembang di masa yang akan datang dan tidak berada di jalan lagi. Hal ini sesuai dengan teori tujuan kecakapan hidup menurut Kamil (2012:130-131) yaitu tujuan utama peningkatan pendidikan kecakapan hidup adalah untuk menyiapkan masyarakat agar yang bersangkutan mampu, sanggup, dan terampil menjaga kelangsungan hidup dan berkembangnya di masa datang. Esensi dari peningkatan kecakapan hidup adalah untuk meningkatkan relevansi pembangunan dengan nilai-nilai kehidupan nyata, baik preservatif maupun progresif.

\section{a. Kegiatan Program Penghalauan}

Menghalau menurut Kamus besar bahasa Indonesia (KBBI) merupakan menyuruh pergi atau mengusir, sedangkan menurut Ibu Hendri selaku anggota dari Dinas Sosial menjelaskan bahwa penghalauan merupakan suatu proses yang dilakukan oleh Petugas Pos Sahabat Anak (PSA) untuk mendata anak- anak yang berada di jalan dan memberikan peringatan agar tidak berada di jalan kembali. Kegiatan program penghalauan pada anak jalanan tersebut yaitu dengan cara mendatangi lokasi terlebih dahulu atau mensurvey kemudian pihak dinas sosial khususnya petugas pos sahabat anak mendatangi dan mengahalau anak jalanan tersebut dengan mendatanya dengan formulir pendataan anak jalanan setelah di data maka akan di 
berikan pelatihan agar tidak berada di jalan

\section{b. Kegiatan Program Pelatihan} kepemimpinan

Menurut Nadler dalam anwar (2012:163) pelatihan merupakan pembelajaran pengembangan individual yang bersifat mendesak karena adanya kebutuhan sekarang, sedangkan menurut menurut Anwar (2012:169) mengemukakan bahwa pelatihan adalah suatu usaha berencana yang diselenggarakan suapaya dicapai penguasaan keterampilan, pengetahuan, dan sikap yang relevan dengan kebutuhan peserta pelatihan. maka dapat disimpulkan bahwa pelatihan merupakan suatu kegiatan atau proses pendidikan yang bertujuan untuk mengembangkan pengetahuan serta ketrampilan yang dimiliki. Proses kegiatan program pelatihan kepemimpinan pada anak jalanan tersebut yaitu anak-anak yang di ajak itu adalah anak jalanan yang sudah ada pembinaan dari penghalauan, maka selanjutnya di bina lagi mengenai pelatihan-pelatihan untuk merubah mindset mereka dari mulai motivasi, pembinaan, sharing mengenai permasalahan mereka, ada materinya juga mengenai karakter dan pengaruh negatif di jalan seperti narkoba minuman keras dan ada pelatihan ketrampilan kejuruan seperti kewirausahaan agar anak tersebut memiliki skill. Dan apabila sudah ada dana untuk pelatihan ketrampilan khusus maka dia sudah mendapatkan informasi dari pelatihan kepemimpinan tersebut. Pelatihan kepemimpinan tersebut juga dihadiri oleh orang tua anak jalanan banyak juga orang tua yang menyuruh anaknya untuk berada di jalan, makanya orang tua mereka juga perlu di rubah mindset nya agar memiliki kegiatan positif.

c. Kegiatan

Program

\section{Kewirausahaan}

Program kewirausahaan pada saat peneliti melakukan penelitian belum terlaksanan namun untuk pelatihannya sudah di berikan pelatihan pada kegiatan program pelatihan kepemimpinan, hanya saja belum terlaksananya proses pemberian dana kepada anak jalanan tersebut sebagai modal dalam kegiatan program kewirausahaan. Dalam kegiatan tersebut pihak dinas sosial 
memberikan bantuan kepada anak jalanan untuk berjualan pulsa yang sudah di paparkan di kegiatan pelatihan kepemimpinan, dari kegiatan terebut akan di berikan modal dari dinas sosial, dan bertujuan agar anak jalanan tersebut memiliki kesibukan yang bermanfaat, memiliki kemampuan dan tidak berada di jalan lagi.

\section{Hambatan yang dilakukan Dinas} Sosial dalam Membentuk Life Skill Anak Jalanan di Kota Serang

Dalam pelaksanaan pasti adanya suatu hambatan begitu pula dalam membentuk Life Skill anak jananan terdapat berbagai hambatan yang dihadapi oleh Dinas Sosial baik hambatan Internal maupun hambatan Eksternal. Hambatan Internal yaitu meliputi hambatan dalam menentukan program yang akan dilaksanakan yaitu pertama mengenai proses pengajuan program yang banyak berbenturan pendapat dan kesalah pahaman karena miskomunikasi terhadap pihak yang terkait, yang kedua terkait sasaran yaitu peserta yang mana sulit untuk dihubungi kembali untuk melaksanakan program selanjutnya. Dan Hambatan dalam sarana dan prasarana yaitu kantor dinas sosial kota serang yang masih mengontrak atau menyewa dan rumah singgah untuk anak jalanan yang belum di optimalkan seperti belum ada pembinaannya.

Hambatan Eksternal mengenai Hambatan dalam penjaringan atau penghalauan anak jalanan yaitu anak jalanannya suka kabur karena bocornya informasi proses pengahaluan. Dan hambatan dalam penanganan permasalahan anak jalanan yang pertama adalah kurang terbukanya anak jalanan tersebut terhadap masalah yang di hadapi yang kedua sulit untuk merubah mindset anak jalanan tersebut dan orang tua yang menghalangi proses tindak lanjut dalam penanganan anak jalanan.

\section{KESIMPULAN}

1. Peran Dinas Sosial dalam Membentuk Life Skill Anak Jalanan di Kota Serang melalu pembinaan mengenai Kecakapan Mengenal Diri Kecakapan Berfikir Rasional Kecakapan Sosial Kecakapan Akademik dan Kecakapan Vokasional yang dilakukan diprogram pelatihan kepemimpinan.

2. Kegiatan yang dilakukan Dinas Sosial dalam Membentuk Life Skill Anak Jalanan di Kota Serang yaitu 
kegiatan penghalauan, kegiatan pelatihan kepemimpinan dan juga kegiatan kewirausahaan

3. Hambatan yang dialami Dinas Sosial dalam Membentuk Life Skill Anak Jalanan di Kota Serang yaitu adanya hambatan internal dan eksternal yang mana hambatan internal meliputi hambatan dalam pengajuan program dan sasaran peserta dan hambatan eksternal meliputi hambatan penjaringan atau penghalauan anak jalanan yang mana anak tersebut sering kabur dalam proses penghalauan, sulit untuk merubah mindset anak jalanan tersebut dan orang tua yang menghalangi proses tindak lanjut dalam penanganan anak jalanan.

\section{DAFTAR PUSTAKA}

Anwar. 2012. Pendidikan Kecakaoan Hidup (Life Skill education). Bandung : ALFABETA

Kamil, Mustofa. 2012. Model Pendidikan dan Pelatihan. Bandung : ALFABETA

Sugiyono. (2017). Metode Penelitian Kuantitatif, Kualitatif, dan $R \& D$. Bandung: ALFABETA

Suharto Edi. (2011). Kebijakan Sosial Sebagai Kebijakan Publik. Bandung : ALFABETA

Sutardi (2016). Solusi Mahir Kimia. Yogyakarta : CV BUDI UTAMA
Tanzeh Ahmad (2009). Pengantar Metode Penelitian. Yogyakarta : TERAS

Tim Pengembangan Ilmu Pendidikan (2007). Ilmu \& Aplikasi Pendidikan.

Undang-Undang Republik Indonesia Nomor 35 tahun 2014 (tentang perubahan atas Undang-Undang Nomor 23 Tahun 2002 tentang perlindungan anak)

Undang-Undang Dasar 1945 Pasal 34

Depdiknas, (2007:10-14). Konsep Pengembangan Model Integrasi Kurikulum Pendidikan Kecakapan Hidup(Pendidikan Menengah), (Jakarta: Badan Penelitian dan Pengembangan Pusat Kurikulum.

Peraturan Daerah nomor 2 tahun 2010 tentang pencegahan, pemberantasan dan penanggulangan penyakit masyarakat, pada bab III tentang klasifikasi penyakit masyarakat https://www.kemsos.go.id/content/anakjalanan kementrian sosial republik Indonesia (diakses hari rabu 13 Februari 2019 jam 12.45 WIB) https://artikelsiana.com/2014/10/pengertia n-peran-apa-itu-peran.html

Pengertian Peran (diakses hari jumat 22 Februari 2019 jam 09.42 WIB) https://dinsos.Serangkota.go.id/ancomponent/media/upload-gambarpendukung/Renstra2014-2018.pdf (Renstra dinas sosial kota Serang 
diakses hari senin 18 maret 2019 jam

01.27 WIB)

https://kbbi.web.id>moral (diakses tanggal

18 Maret 2019 jam 02.28)

https://kbbi.web.id>halau (diakses tanggal

1 Desember 2019 jam 20.32) 